\title{
Amber, a Stone of Sun for Ancient Medicines ${ }^{1}$
}

Amber, a gem that has been very appreciated since antiquity, was used also as an amulet and a medicine. All the most outstanding medical treatises of the past tell about the therapeutic properties attributed to amber, and report singular recipes to obtain pharmaceutical preparations. Amber was much-sought for this use until the middle of XIX century, but with the beginning of the modern medicine, its use disappeared, carrying with it the memory of ancient times.

Since ancient times, amber has been considered a peculiar gem that has been linked to the sun. According to a legend, sun rays hit the ground during the sunset hours and give birth to a fluid that, after dropping in the ocean, is transformed into amber, which can be collected onshore. Amber was called elektron by ancient Greeks, meaning "shining thing", like Elektor, one of the several names used to call the Sun, and Elektris, the Moon mentioned in the Orphic Hymn to the Moon. Amber is strictly linked to the solar myth also by the legend of Phaeton (his name means "shining" too), son of the Sun. The precious material, amber, was supposed to origin from the tears of the Heliades, Phaeton's sisters transformed into poplars, and found in the river Eridanus (identified as the Italian river Po, but also referred to several other rivers throughout Europe). Amber has been often included into the so-called "solar things" of the materia medica.

1 This article refers to some topics published in the book (in Italian) written by the author, entitled "L'ambra, farmaco solare. Gli usi nella medicina del passato". Zielo Publisher, Padova, 2005; the subject was also presented as an invited lecture at the International Meeting of the European project "Amber expedition". 


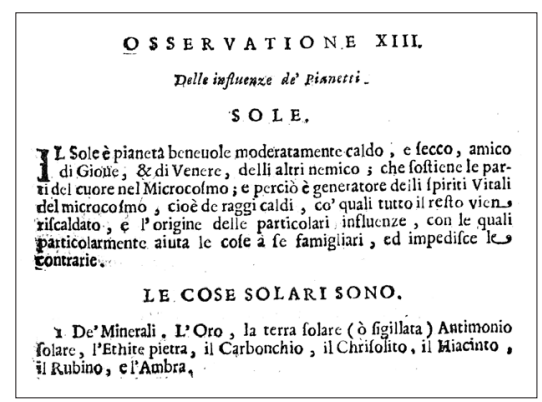

Solar things, linked to the sun (Sole); the last in the list is amber (Ambra).

From Nuovo Tesoro degl' Arcani

Farmacologici, Galenici

\& Chimici ò Spargirici by Felice

Passera, 1688
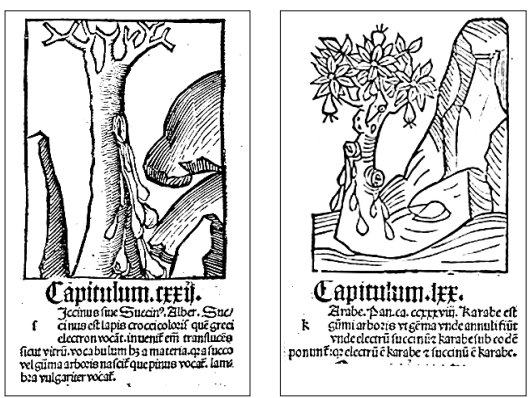

Ancient trees with big drops oozing from the trunk, from Ortus sanitatis,

Tractatus de lapidibus (1497).

Both images show the formation of amber, that here is presented as two apparently different substances, called "succinus" and "karabe", respectively

The Romans used to call amber as sucinum (juice), because they learned it was a juice of a tree, that is, a true resin. In the treatise Ortus sanitatis ${ }^{2}$ two drawings show ancient trees with big drops of resin oozing from the trunk, destined to become amber. Pliny the Elder, author of the I century A. D., was convinced that amber is a resin of old pines, growing in the regions touched by the northern Ocean, maybe the Avalon isle, in the land of Hyperboreans, hit by the cold wind of the North. Among the many other hypotheses on the origin of amber, Pliny says that it is called by Germans glesso (from this term comes the modern English term "glass"), originating in the "Glessaria" islands in the Northern Sea, and it flows from pine-like trees, as can be read in the original description: "... cola da gli alberi di spetie di pino, come cola la gomma da ciriegi, \& la ragia da pini per abbondatia d'humore. Congelasi o per freddo, o peltempo o pel mare, \& quando l'onde lo rapiscono lo trasportano a liti in forma volubile che pare stia sospeso". ${ }^{3}$ Pietro Andrea

2 Anonymous (1497). Ortus sanitatis: Tractatus de lapidibus. - Johann Prüss, Strasbourg Anonymous Il $91^{\circ}$ Congresso dei Naturalisti e Medici Tedeschi // Giornale di Chimica Industriale ed Applicata, Anno XII, 1930; 10: 505.

3 Plinio il Vecchio - Pliny the Elder, Naturalis Historia, translation in ancient Italian by Cristoforo Landino, Venezia, Gabriel Giolito de' Ferrari, 1543, book XXXVII, chapter III. 
Mattioli from Siena (Italy), who graduated in 1523 from the University of Padua Medical School, says that amber is a "licore di un albero", a juice from a tree 4 . The property of attracting lightweight objects after rubbing amber suggested the Persian name karabe, "straw attractor", sometimes written as carabe, kakrabe, katabre, kacabrates; Mattioli used also the word pterygophon, that means "feather attractor". Tradition linked to fantasy, emphasised by the solar myth, attributed to this peculiar substance a large number of properties in medical field 5,6,7,8, as remedy for many diseases, besides its use as an amulet. In the dissertation De succini natura $(1614)^{9}$, chaired by Adrian Pauli (1583-1622), a physiology professor from Gdańsk, it is possible to read that "there is no part of the body that cannot receive benefits from amber".

Pliny the Elder, in his Naturalis Historia wrote extensively about amber. ${ }^{10}$ He reported that the inhabitants of the Veneto region (Northern Italy), called "Eneti" by Greeks, gave fame to this substance (" $i$ Venet $i, i$ quali i Greci chiamano Eneti, hanno dato fama alla cosa"), after they received it from people living in Pannonia, the ancient province of the Roman Empire bounded north and east by the Danube, along the so-called Amber Route. Pliny states also that it is true that amber is found in the region of the Po River, because local countrywomen wear amber as necklace and use it as medicine ("la favola la quale vuole che [l'ambra] nasca in Po, perché ancora hoggi le femine villane, et agresti oltra a Po, portano l'Ambre in collane per ornamento, et anchora per medicina").

4 Mattioli P. A. Commentarii, in Libros sex Pedacii Dioscoridis Anazarbei, de Materia Medica, Adjectis quàm plurimis plantarum \& animalium imaginibus, eodem authore, Valgrisi. - Venezia, 1554.

5 Ragazzi E. L'ambra nella medicina del passato / L'ambra, scrigno del tempo Museo di storia naturale di Montebelluna. - Sommacampagna: Cierre Edizioni, 2000. - Pp. 47-52.

${ }^{6}$ Ragazzi E. L'ambra, farmaco solare: Gli usi nella medicina del passato. - Padova: Zielo Editore, 2005. - P. 116.

7 Ragazzi E. L'ambra in medicina: Ambra - Il fascino di una gemma fra mito scienza e vanità / Editor: E. Trevisani. - Bologna: Minerva edizioni, 2007. - Pp. 42-49.

8 Duffin C. J. Fossils as Drugs: pharmaceutical palaeontology / Chapter on Amber. - Ferrantia 54, 2008. - Pp. 44-67.

9 Gelnitius A. Disquisitio philosophica de succini natura / Pauli A. (praes.). Dantisci; ex Molibdographia Hünefeldiana, 1614.; Nothnagel E. Manuale di Materia Medica e Terapia. - Napoli: Giovanni Jovene Libraio Editore, 1876.

10 Translation in Italian by Cristoforo Landino, Venezia, Gabriel Giolito de' Ferrari, 1543, book XXXVII, chapter III. 
Surely the fact that amber is warm, differently from other mineral gems, its peculiar lightness and its electrostatic property (as above mentioned, the ancient name of amber in Greek was elektron, from which the term "electricity" was coined) all contributed to believe in its apotropaic and even therapeutical properties.

Browsing the old books of Materia Medica (for example the classical treatises by F. Passera ${ }^{11}, 1688$ and by G. Donzelli12, 1737), it is frequent to find recipes to prepare medicines containing amber. Amber as a drug was a deeply argued topic in the antiquity. Mystery regarding amber's supposed properties emerges also looking at the alkemic symbol used for amber (succinum): it is often represented with two partially overlapping circles crossed by a horizontal line. The crossed circle was used to mean "salt", as a common material for obtaining the philosopher's stone and as symbol of wisdom; therefore it is easy to believe why amber and its medicinal preparations were considered as a concentrate of healthy energy. For this reason amber was used to treat almost every kind of illnesses. The double circle of its symbol can be intended also as a way to enhance the meaning. Moreover, the solar link occurs again: the symbol used for sun and for gold is a circle with a dot in the centre, this being a recurrent symbol since prehistory.

With the development of Renaissance medicine, more and more books considered amber for its medicinal properties. Appendix reports main treatises and theses discussing uses of amber in medicine that were published since XVI century. The Italian Felice Passera, a Capuchin monk from the Infirmary of Brescia, Northern Italy (Cappuccino Infermiero della Provincia di Brescia), in his treatise Il Nuovo Tesoro degl' Arcani Farmacologici Galenici, \& Chimici, o Spagirici ${ }^{13}$ describes in short, but in a very efficient way, the believed medicinal properties of amber: "Scalda, dissecca, astringe leggermente, conforta, corrobora" (It heates up, desiccates, slightly astringes, comforts and corroborates). The many properties of amber for internal use are enumerated: it was used against " $i$ morbi del capo, i morbi humidi della testa"

11 Passera F. Il Nuovo Tesoro degl' Arcani Farmacologici Galenici, \& Chimici, ò Spagirici. - Venezia: Giovanni Parè, 1688.

12 Donzelli G. Teatro Farmaceutico, Dogmatico, e Spagirico del Dottor Giuseppe Donzelli. - Venezia: Andrea Poletti, 1737.

13 Passera F. Il Nuovo Tesoro degl' Arcani Farmacologici Galenici, \& Chimici, ò Spagirici. - Venezia: Giovanni Parè, 1688. 
(head diseases, humid diseases of the head) and also to treat catarrh, epilepsy, apoplexy, dizziness. It was reported to be effective against asthma, cough and all the most serious diseases of the lung ("giova e convien a quelli che gettano sangue dalla bocca"). It was believed useful to cure urinary retention caused by painful kidney stones (" $m a l$ della pietra"); it is possible to read also the anecdotal case of a man that, after taking amber mixed with wine and Jerusalem thorn, "mandò fuori l'orina ritenuta già per XV giorni" (expelled urine after retaining it for 15 days). It was also believed that amber, easily powdered using a mortar, dispersed in water and drunk alone or with mastic tree resin, was effective to cure stomach diseases.

Amber was not only a gemstone very appreciated by ladies, by wearing it as a necklace or as other jewels, but it was also used to cure woman's diseases: "provoca li mestrui e singolarmente frena la strangolation dell'utero" (it induces menstruation and is effective in solving womb spasm). Moreover, it was thought useful in difficult labour, since powdered amber, mixed with white wine, seemed to make childbirth easier and faster ("rende leggiero il parto"), according to reported author's experience..$^{14}$ A frequent use of powdered amber, mixed with liquors or wine was during plague spread in the cities of all Europe, including Venice, Italy. Jan Baptista van Helmont (called Elmonzio in Old Italian language ${ }^{15}$ ) quotes in his Opuscula medica inaudita ${ }^{16}$, in the chapter De peste (pp. 149): "Nil saltem stomacho, intestinis, nervis, imo \& cerebo gratius, succino in vini spiritu resoluto." (There is no disease of the stomach, gut, nerves, and mostly brain that amber, dissolved in wine, cannot heal.) To prevent the disease, amber was also recommended as amulet, rubbing often wrists with it. Matthaeus Praetorius ${ }^{17}$ wrote that during the pestilence, no amber fisherman of Danzig, Klaipeda, Königsberg or Liepaja died of plague.

14 Passera F. Il Nuovo Tesoro degl' Arcani Farmacologici Galenici, \& Chimici, ò Spagirici. - Venezia: Giovanni Parè, 1688.

15 Donzelli G. Teatro Farmaceutico, Dogmatico, e Spagirico del Dottor Giuseppe Donzelli. - Venezia: Andrea Poletti, 1737.

16 Van Helmont J. B. Opuscula medica inaudita: IV. De peste, apud Jodocum Kalcoven, Coloniae Agrippinae. - 1644.

17 Praetorius M. Deliciae Prussicae oder Preussische Schaubuehne. - Klaipeda, 1680. 

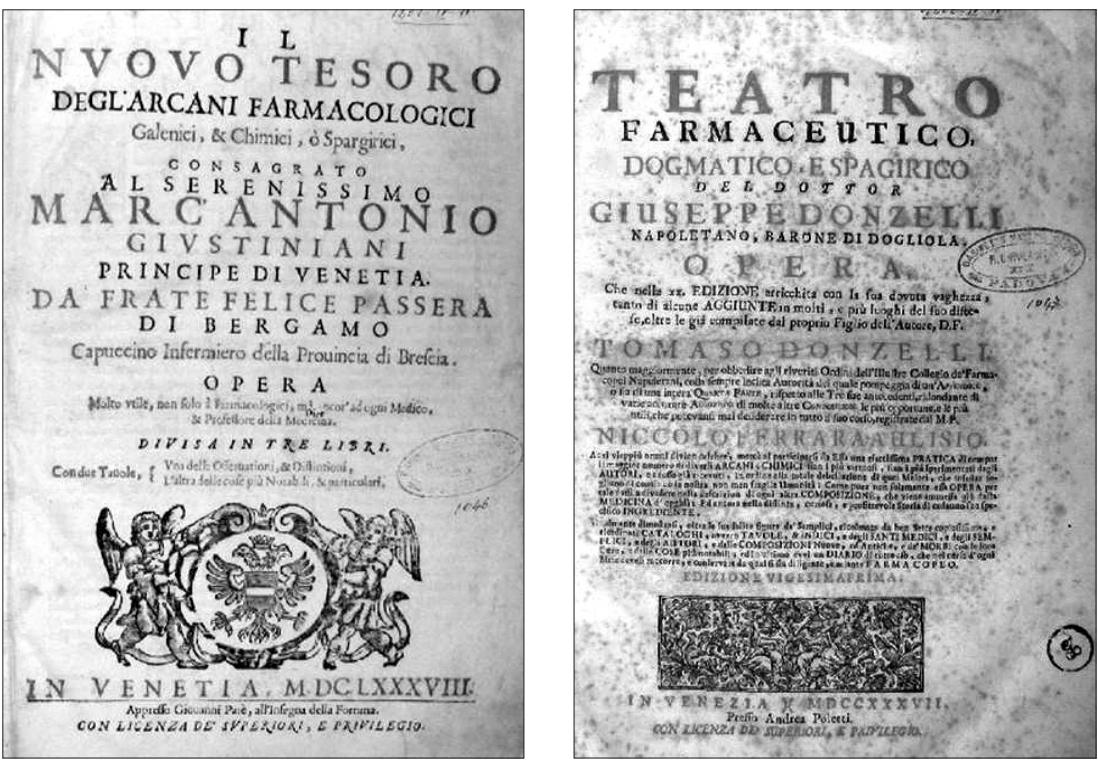

Title page of two classical treatises of Materia Medica, by Passera F. (1688) and by Donzelli G. (1737). Originals are conserved in the historical section of the Library of the Department of Pharmacology \& Anesthesiology, University of Padua
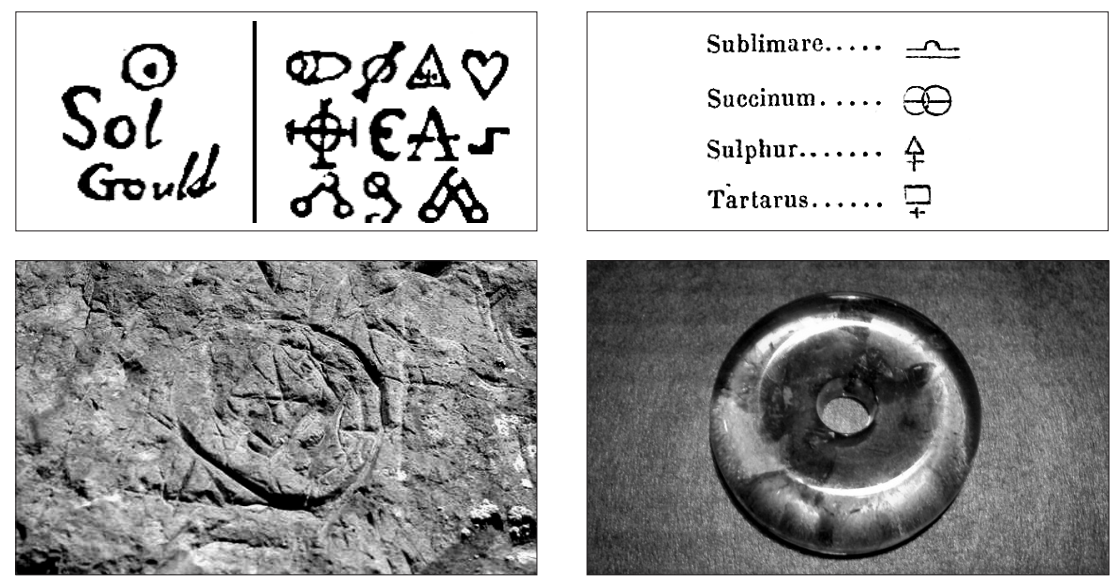

The alchemic symbol for sun (sol), gold (gould) and amber (succinum).

Analogies with ancient solar symbols engraved in the rocks of Tunkelbald

(Val d'Assa, Veneto Region, Italy), and reconstruction in amber of a solar disk amulet (down right) 
A reason for the success of this treatment with amber probably depended just on the healthy life of amber fishermen working along the Baltic shore, preventing in this way the infection, spread out by fleas of rats in crowded cities. Among the several possibilities of amber use as a topical remedy, Passera suggests to wear a piece about the neck against eye and throat diseases. For curing sore throat (schiranzia) it was advised to burn small pieces of amber in a bowl, and then inhale the smoke for two or three times: "se rotto in pezzetti e posto sopra la bornice in una scodella, si come si sol fare con l'incenso, e coperta con un pedriolo si faccia ricever il fumo al patiente in modo che vada alla gola e ciò per due o tre volte". Another remedy for the schiranzia was the inhalation of impalpable amber powder with a strow: "con canetina si soffiarà nella gola ove è l'infiammazione, o tumore". The smoke from amber burning was thought useful also to heal epilepsy, rheumatic diseases and neuralgia. ${ }^{18}$ Often the powder obtained from the work of amber carving in Sicily (using the well-known simetite) was sold cheaply to people and used burned to cure various illnesses, directing the smoke on the affected part by means of a cone made with paper (according to Francesco Ferrara, Professor of Physics at the University of Catania $\left.{ }^{19}\right)$.

Smoke, here employed to administer a medicine, is again linked to the world of amber. The Semitic triconsonantic term MBR was used to mean something of fragrant, and also amber, which is resinously fragrant when burned. "Perfume" is also a term linked to the Latin word perfumum (through smoke), that is the atavistic use of burning resins to raise pray to heaven. The present day term to name amber in German is Bernstein, derived from Bernen and Stein that is "stone that burns". Antonio Stoppani hypotesised that "amber" derives also from a similar etymology, from the Belgian anbernen, that means "burning", the typical property of amber. ${ }^{20}$

Wearing a necklace of amber beads was believed to be a remedy against every disease in little babies, and a protection against secret poisons and countercharm against witchcraft and sorcery ("incanti, fascinationi o malefici e contro i demonij, onde giova a qualunque si sia inspiritato e a timori

18 Cantani A. Manuale di Farmacologia Clinica. - Vol. II. - Milano: Vallardi, 1887. - Pp. 276-278.

19 Ferrara F. Memorie sopra l'ambra siciliana. - Palermo: Reale Stamperia, 1805.

20 Stoppani A. L’ambra nella storia e nella geologia. - Milano: Dumolard, 1886. 
notturni", Passera, 1688). Also today a popular tradition suggests making children wear necklaces of amber. Moreover, pieces of amber were used to soothe the gum pain of small children during dentition ${ }^{21}$, and this practice is retrieved also today, although plastic devices are more often employed. This tradition should be discouraged, since getting babies to wear necklaces or letting them play with these artifacts may cause suffocation.

In Mexico people use amber necklaces against the "aire", a disease considered to be caused by wind, according to a common belief among populations of South America, and linked to ancient Aztec medicine. ${ }^{22}$ According to ancient books ${ }^{23}$, gold-coloured amber, weared on the neck, is able to heal fever and other illnesses ("guarisce la febbre e altri mali").

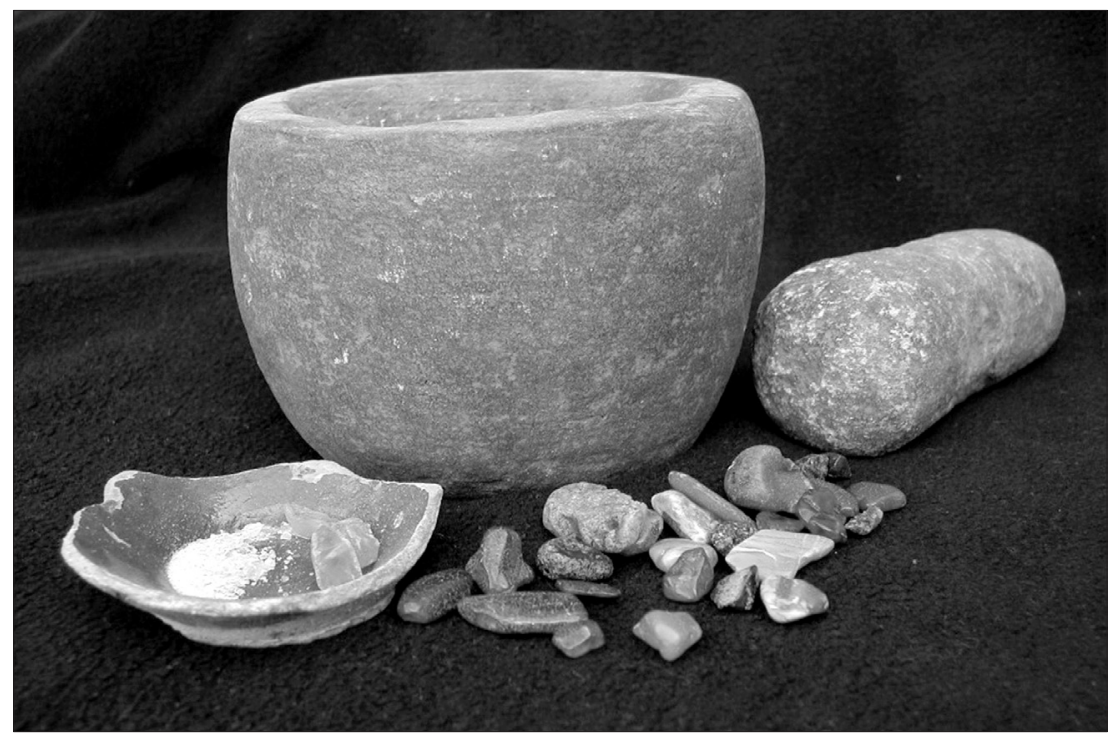

Amber, pulverised in a mortar, was a common material to obtain ancient pharmaceutical preparations

${ }^{21}$ Hildburgh W. L. Notes on some Burmese amulets and magical objects // J. Royal Antropological Inst. of Great Britain and Ireland, 1909; 39: 397-407.

22 Scarpa A. Itinerario per la visita al museo di etnomedicina "Collezioni Antonio Scarpa". - Genova: Erga Edizioni, 1994.

${ }^{23}$ Passera F. Il Nuovo Tesoro degl' Arcani Farmacologici Galenici, \& Chimici, ò Spagirici. - Venezia: Giovanni Parè, 1688. 
Mixed with honey and oil of rose, it is reported to be effective against ear discomfort, and in particular, if mixed with Athenian honey, clears the sight ("leva l'oscurità delli occhi"). More recently, in the late 1800, Antonio Cantani, professor of Medical Clinics at the University of Naples, raises some doubts about amber activity in diseases, although common people still wear amber, hoping to get an effect linked to its healing electrical properties ("il volgo porta anche il succino in sostanza addosso al corpo nudo, sperando da esso un'azione antireumatica e profilattica contro i raffreddamenti, sperando cioè nelle supposte proprietà elettriche del succino"24).

A peculiar use of rounded and polished pieces of amber ${ }^{25}$ was to remove dust from the eyes; popular wisdom observed that it is dangerous to touch the eyes with fingers when a small foreign body has entered, and in this situation amber can help.

\section{Ancient Medicinal Preparations Containing Amber}

Amber (ambra in Italian, but named also succino or carabe in Medieval time) in ancient pharmacopeias was included in the chapter of "marine bodies" (corpi marini), in particular among those that have astringent properties. This classification probably derived from the fact that amber has been found very often on the shore of the Baltic Sea, after being eroded from undersea deposits, and therefore believed as a material originated from the sea. Amber should not be mixed up with ambergris (ambra grigia, literally "grey amber", a gastric secretion of sperm whale), that is also found in the shore and that is still today considered as a precious ingredient for making perfumes. A distant etymological link joins ambergris with amber: according to a hypothesis, the term "amber" used today originated in Medieval time from a mistake, an exchange of terms between ambergris (in Arabic anbar) and real amber. Both materials commonly share the same marine origin, the intense scent produced if heated, and their use in ancient medicine.

${ }^{24}$ Cantani A. Manuale di Farmacologia Clinica. - Vol. II. - Milano: Vallardi, 1887. - Pp. 276-278.

25 Kosmowska-Ceranowicz B., Konart T. Tajemnice bursztynu. - Warszawa: Muza SA - Sport I Turystyka, 1995. 
Sometimes amber was classified among sulphurs, such as in the book Pammineralogicon by the English naturalist Robert Lovell ${ }^{26}$, or also among Bitumina, according to the Italian medical doctor Ludovico Tessari ${ }^{27}$. The most common ancient medicinal preparations of amber are reported below ${ }^{28}$; for detailed enumeration of the medical applications of amber in the past centuries see Duffin 29 .

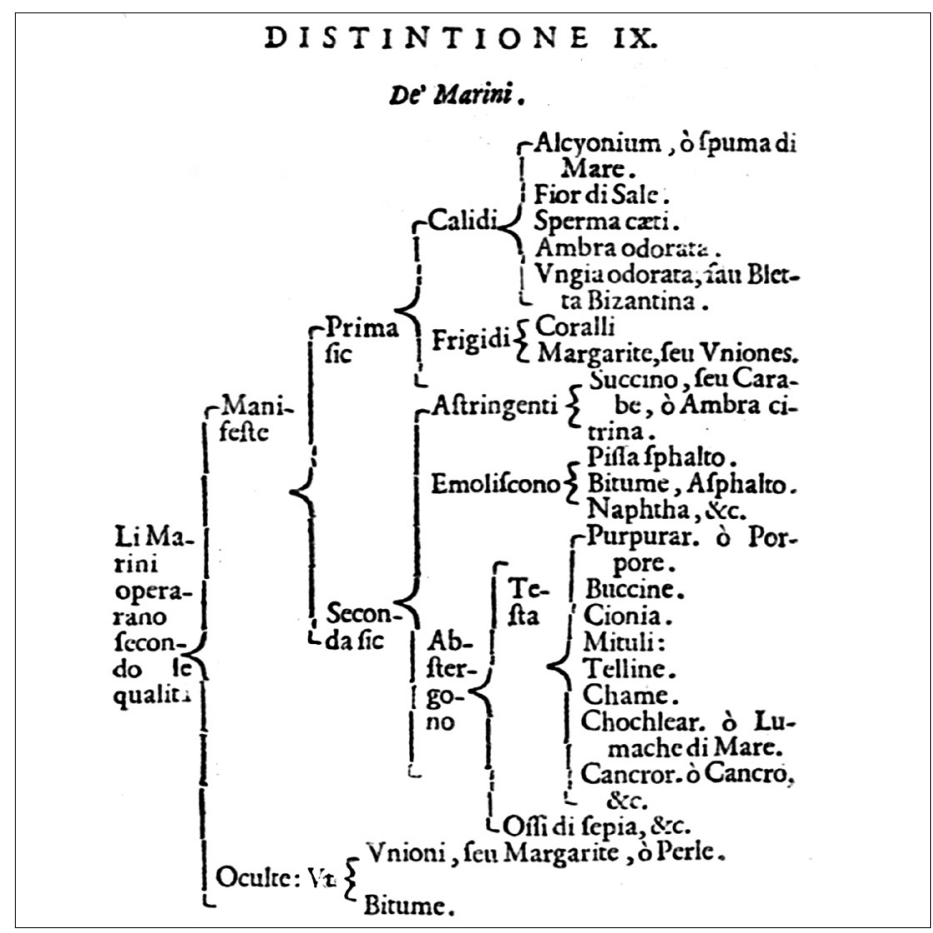

The classification of succino (carabe or ambra citrina) and of ambra odorata (ambergris); both included among the remedies of marine origin, the so-called "marini” (Passera F., 1688)

${ }^{26}$ Lovell R. Pammineralogicon. - Oxford: R. Godwin, 1661.

27 Tessari L. Materia Medica Contracta. - Venezia: Pezzana, 1742.

28 Ragazzi E. L'ambra, farmaco solare: Gli usi nella medicina del passato. - Padova: Zielo Editore, 2005. - P. 116.

29 Duffin C. J. Fossils as Drugs: pharmaceutical palaeontology. Chapter on Amber. Ferrantia, 2008; 54: 44-67. 


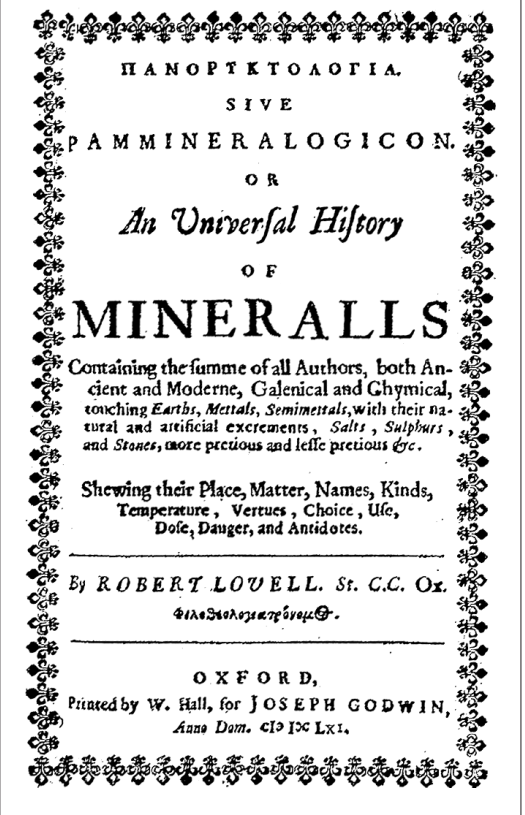

\section{Theiologia.ofsulpbur. 5}

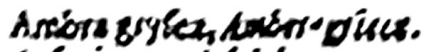
Askaicum, tilnick Ágínilsos, Affóls. Gozies, Alub.

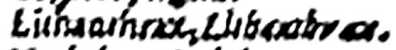
Nefilima, Hafers.

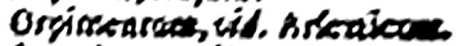

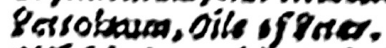

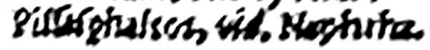
Susdarstansile Arkeniosta. Spesmas Ceci, 8 promassio. Sccisusm, Amirr.

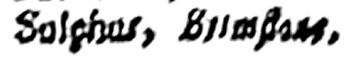

Yellow amber and ambergris, both were considered among the class Sulphurs. From Pammineralogicon,

by Robert Lovell, Oxford, 1661

Succino preparato (amber preparation): comminuting amber was obtained on a porphyry slab or mortar and adding appropriate solvents (water, wine, beer, milk). After drying, it was conserved ready for use. A common usage of "succino preparato" was in the classical preparation called "Pillole di succino" or "Pillole di carabe" (amber pills) that has been reconstructed ${ }^{30}$ according to an old recipe proposed by Craton, alias Johannes Crato von Krafftheim (1519-1585), who studied medicine at the University of Padua, and then became an imperial physician of Rudolph II. The recipe is reported in the Antidotarium Bononiense ${ }^{31}$ and in the Codice Farmaceutico per lo Stato della Serenissima Repubblica di

30 Ragazzi E. L'ambra, farmaco solare: Gli usi nella medicina del passato. - Padova: Zielo Editore, 2005. - P. 116.

31 Antidotarium Bononiense ex typographia Laelii a Vulpe. - Bologna, 1750. 
Venezia. ${ }^{32}$ Among the various proposed uses, it is to mention the effectiveness to "depurate the body" (obsolete term to indicate a remedy supposed to promote the elimination of waste products from the body), to heal head diseases (Antidotarium Bononiense: "In capitis affectibus singulariter conveniunt"33) and to clear the "darkness of the mind" (Passera: "purgano benignamente il corpo" e "cavano i bigiori della testa e li scacciano"34). The presence of condensed juice of aloe, a drastic laxative containing anthraquinones, explains the activity observed at gut level. To avoid unwanted side effects, the author suggests taking it twice per month. Amber was also the main ingredient of the pulveris dysenterici Crollii ${ }^{35}$, used against diarrhoea. Pulverised amber was one of the ingredients of the Electuario gemmis ${ }^{36}$, a mixture of several gems, used for various diseases, such as heart and gut diseases.

Olio di succino (Oil of amber): it is the best-known amber preparation, also called olio empireumatico di succino or olio volatile di succino. It was produced in several ways, based on the alkemical process of dry distillation. Following another distillation with water, the refined oil of amber (olio di succino rettificato) was obtained. ${ }^{37}$ Some authors preferred to employ yellow amber to get the oil, but others believed that white amber was better. The process was as follows ${ }^{38}$ : powdered amber was distilled in a glass retort placed over fire ("distillasi per storta di vetro, over di terra ben vetrata postosi sotto il fuoco, a poco a poco cautamente"); first "phlegm" (flemma) will come out, then a lighter oil, and finally a thicker oil; the "volatile salt"

32 Codice Farmaceutico per lo Stato della Serenissima Repubblica di Venezia. Padova: Stamperia del Seminario, 1790.

33 Antidotarium Bononiense ex typographia Laelii a Vulpe. - Bologna, 1750.

34 Passera F. Il Nuovo Tesoro degl' Arcani Farmacologici Galenici, \& Chimici, ò Spagirici. - Venezia: Giovanni Parè, 1688.

35 Vesti J., Silberschlang J. E. Disertatio inauguralis medica Succinum, physice et medice consideratum. - Erfordiae: Kindlebiano, 1702.

36 Manlio G. G. Luminare majus, opus eximium quod luminare dicitur Medicis et Aromatariis perque necessarium. - Lugduni: de Gabiano, 1536.

37 Bosio C. O. Trattato di Farmacologia Veterinaria o Materia Medica. - Torino: UTET, 1889.

38 Passera F. Il Nuovo Tesoro degl' Arcani Farmacologici Galenici, \& Chimici, ò Spagirici. - Venezia: Giovanni Parè, 1688. 
(sale volatile) will stick all around the neck of the retort, and in this way it can be taken separately from oil. Oil of amber was called also "opobalsamo europeo", or also "olio sacro" (holy oil), because of its supposed marvellous properties ("per le sue virtù meravigliose et admirande"); it was very often used to treat apoplexy, epilepsy and paralysis and other "dangerous diseases of the head" ("altri morbi pericolosi del capo"). Against colics, it was administered mixed with wine, or externally, greasing the umbilicus (ongendone l'ombelico).

The physician and pharmacist from Naples, Giuseppe Donzelli39, says that with the "balsamo europeo" it is possible to make "tablets with sugar, very useful for every kind of illness" ("tabelle con zucchero, utilissime, si può dire, per ogni sorta d'infermità"). Oil of amber was of use in making the formulation called "Eau de Luce", in Italian Acqua di luce, or Alcool Ammoniacale Succinato, as described in the Farmacopea Ferrarese by Antonio Campana ${ }^{40}$. The origin of the name of this preparation was extensively considered by John Beckmann in his History of Inventions ${ }^{41}$; he wrote that "Some translate it Aqua Luccana, others Aqua St. Luciae; some Aqua Lucii, and some also write it Eau de Lusse. Many, however, are of the opinion that an apothecary at Lisle in Flanders, or at Amsterdam, named Luce, was the inventor". But simply, and most probably, the name "luce" is just the Italian term indicating the light. The acqua di luce was employed as external application to cure rheumatic diseases, or sniffed with caution, as analeptic (central nervous system stimulant) in case of fainting (it contained ammonia). Another use of oil of amber was in the preparation of the "nervine unguent" ("unguento nervino", from the Venetian Pharmaceutical Codex, Codice Farmaceutico per lo Stato della Serenissima Repubblica di Venezia ${ }^{42}$ ). The recipe suggested using sheep grease, pork suet, distilled trementine and distilled oil of amber. After melting together the two greasy

39 Donzelli G. Teatro Farmaceutico, Dogmatico, e Spagirico del Dottor Giuseppe Donzelli. - Venezia: Andrea Poletti, 1737.

40 Campana A. Farmacopea Ferrarese. XV ed. - Pesaro: Tipografia Annesio Nobili, 1831.

41 Beckmann J. A history of inventions and discoveries. - 2 ${ }^{\text {nd }}$ ed. - London: Walker and Co., 1814. - Pp. 597-598.

42 Codice Farmaceutico per lo Stato della Serenissima Repubblica di Venezia. Padova: Stamperia del Seminario, 1790. 
substances under moderate heating, trementine and amber oil were added. After removing the mixture from fire, it had to be mixed until, cooling, it hardened.

Sale volatile di succino (volatile salt of amber): it was obtained as one of the distillation products of amber, as described above. Today we know that it is composed by succinic acid, typical substance present in Baltic amber in no more than $8 \%$ as combined form. Succinic acid is not an exclusive component of amber, since it is a normal metabolite produced through the Krebs' cycle during aerobic biochemical fuel mechanisms in every living organism, humans included. It is also present, although in low concentration, in wine, of which it contributes to determine the taste. Ancient medical treatises acclaimed volatile salt of amber as a cure for paralsy, neuralgia, convulsions, histerisms ${ }^{43}$, but also as expectorant in bronchial catarrh and as diaphoretic in rheumatism ${ }^{44}$. Recent investigations carried out in our laboratory ${ }^{45}$ have demonstrated that succinic acid in free form (available for absorption) in Baltic amber is present only in a very low amount, since it is mostly linked to polymeric molecular structures of the fossil resin, and therefore it is not accessible for a possible absorption from crude amber.

Spirito volatile di succino (volatile spirit of amber): this term was used to identify the aqueous component (flemma, phlegm) that was found as precipitate in the lower part of the flask collecting the distillate of amber, while the upper part was the oil of amber described above. The volatile spirit was a solution of succinic acid, acetic acid and pyrogen oil. This substance was employed to obtain the "amber syrup" (sciroppo di karabe), formerly used as stimulant, antispasmodic and nervine tonic. ${ }^{46}$

${ }^{43}$ Bruschi D. Instituzioni di Materia Medica. Cap. III: Di altri medicamenti che accrescono l'energia vitale del cervello. - Vol. III. - Milano: Tipografia Ferrario, 1834. - Pp. 143-149.

44 Cantani A. Manuale di Farmacologia Clinica. - Vol. II. - Milano: Vallardi, 1887. - Pp. 276-278.

45 Tonidandel L., Ragazzi E., Traldi P. Mass spectrometry in the characterization of Ambers. II. Free succinic acid in fossil resins of different origin // Rapid Commun Mass Spectrom, 2009; 23 (3): 403-408.

46 Medicamenta, Guida Teorico-pratica per sanitari. - Milano: Cooperativa Farmaceutica, 1908. 


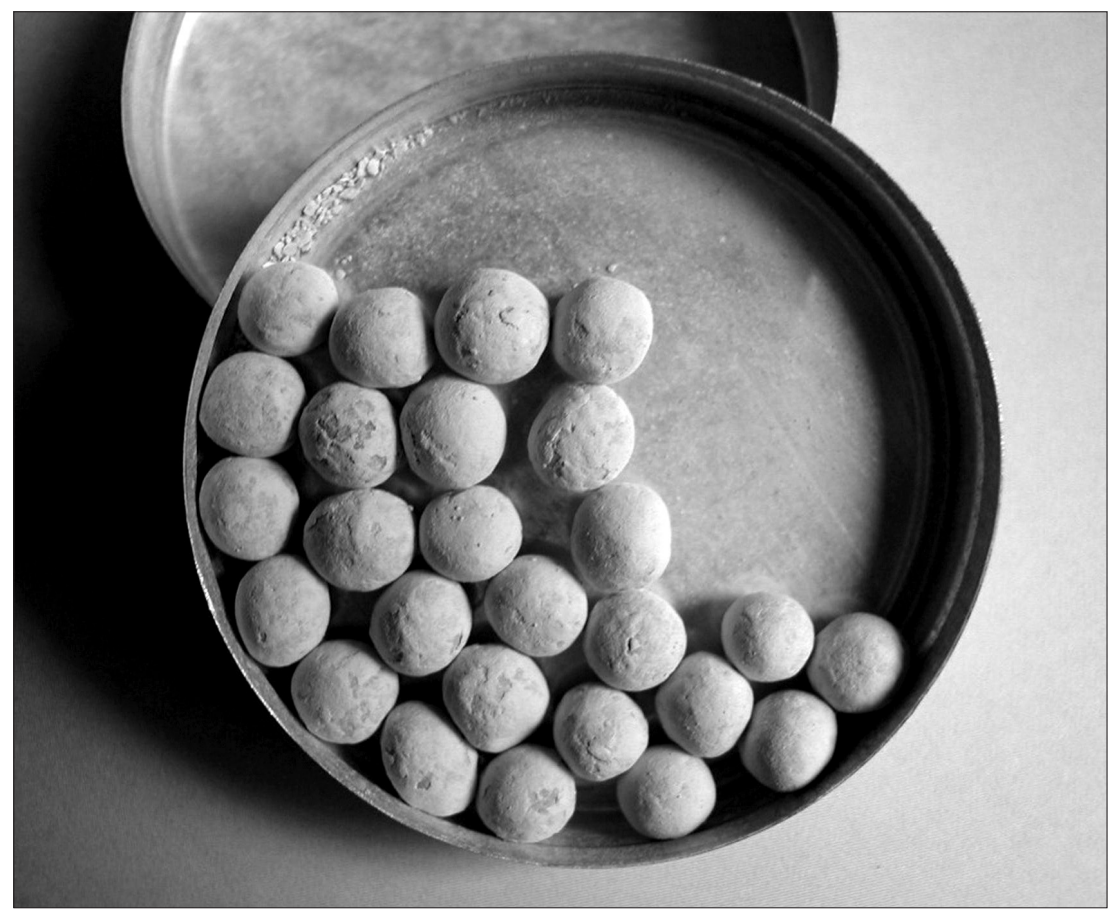

\section{PILULA DE SUCCINO \\ CRATONIS.}

B. Aloes Soccotrinx drachmas decem, Maftiches, Succini, ana drachmas quatuor, Agarici trochifcati Radicum Ariftolochix rotund $x$

$$
\text { - drachmam unam. }
$$

Cum fufficienti quantitate Syrupi de Betonica fiat fecundum artem Maffa pilularis.

In capitis affectibus fingulariter conrveniunt.
Dofis a drachma femis ad dracbmam unam.

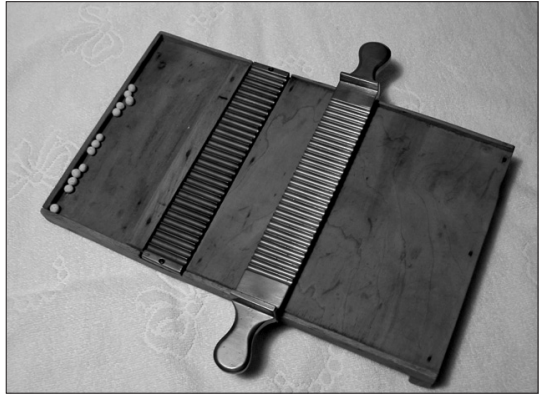

Reconstruction of the pills of amber ("Pillole di succino" or "Pillole di carabe") according to the original recipe by Craton, from the Antidotarium Bononiense (1750).

Lower right image shows the device used to make pills

Trochisci di succino (Amber troches / tablets): the trochisci or trocisci, troches (from the Greek trochískos, diminutive of trochós, wheel) are ancient pharmaceutical preparations with discoidal or diamond shape ("simili alle 
foglie del Mirto", similar to myrtle leaves) ${ }^{47}$, employed for the oral administration of medicines, to be dissolved inside oral cavity, or chewed. They were obtained mixing ingredients with various excipients, such as breadcrumb with water or wine, then allowed for drying. Trochisci of amber, prepared according to Mesuè 48,49 , were used to cure diarrhoea; the presence of opium among the ingredients, explains their effectiveness against this symptom. Passera (1688) suggests them to stop bleeding ("ottimi per fermar qual si voglia Hemorragia”).

ALCOOL AMMONIACALE SUCGINATO.

P. Alcool, un' oncia. Acqua di luce of:

Olio volatile di succino rettificato, uno scropolo.

Sapone di soda bianco, grani due.

Sciogli in boccia chiusa diligentemente, ed al hiquore filtrato agginngi

Ammoniaca concentrata, once quattro.

Il fluido reso cosi latticinoso serbalo in boccia $\mathrm{di}$ cristallo ben chiusa con turacciolo smerigliato. Per rendere piü durevole l' apparenza hatticinosa s'infondono nell' ammoniaca alcune gocce di alcool succinato fetido, e nel momento si ottiene un' oltima acqua di luce.

Uso esterno nelle affezioni reumatiche; odorato con cautela risveglia lo spirito, e nelle asfissie prodotte dal gas acido carbonico e idrosolforico è vanraggioso, inspirandolo.

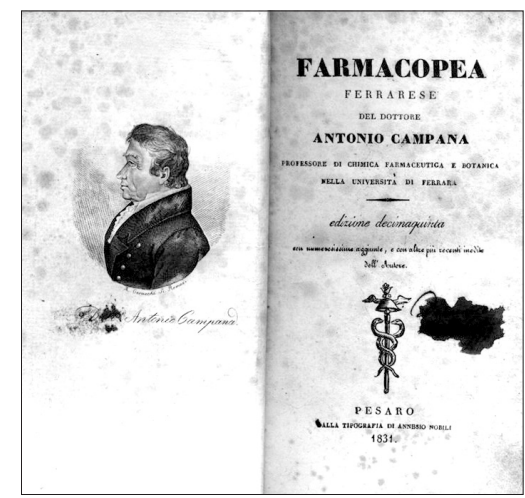

Ingredients of the Eau de luce (acqua di luce), according to the Farmacopea Ferrarese (1831) by Antonio Campana. Lower image shows what the preparation looks like

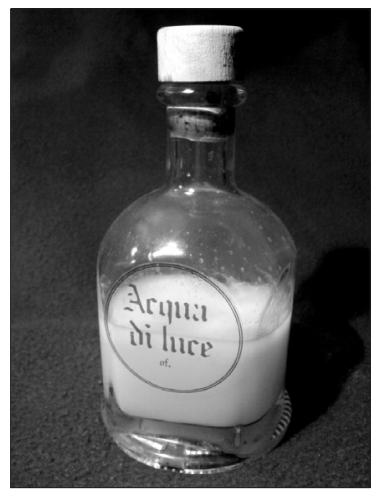

47 Donzelli G. Teatro Farmaceutico, Dogmatico, e Spagirico del Dottor Giuseppe Donzelli. - Venezia: Andrea Poletti, 1737.

48 Antidotarium Bononiense ex typographia Laelii a Vulpe. - Bologna, 1750.

49 Donzelli G. Teatro Farmaceutico, Dogmatico, e Spagirico del Dottor Giuseppe Donzelli. - Venezia: Andrea Poletti, 1737. 


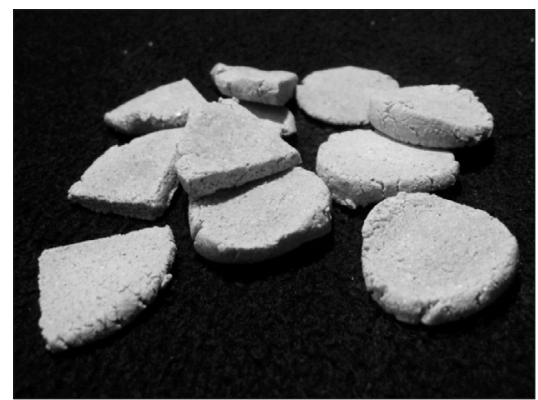

Reconstruction of the trochisci di succino, ancient medicinal preparations with discoidal or lozenge shape

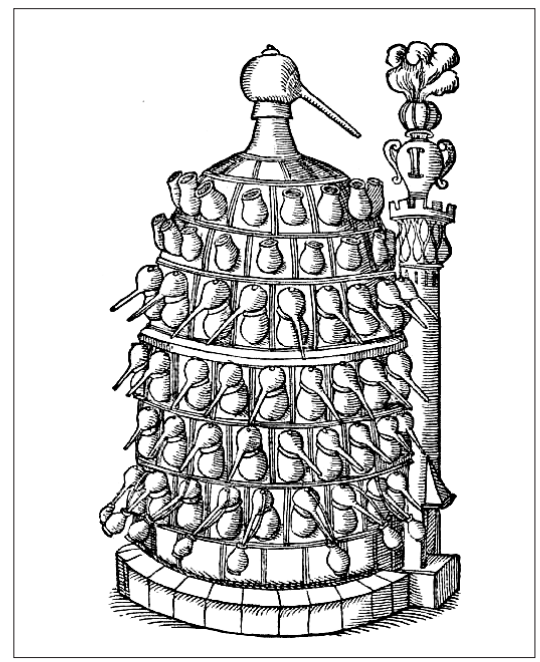

Dry distillation of amber was obtained using complex apparatus, like the above reported, inspired to a hive. From Mattioli, Del modo di distillare, Commentarii, Venezia, Valgrisi, 1554
T R O C I S C I Di Carabe di Mefue.

D Islia di Carabe aurei 6. Corno di Cervo ab. bruggiato, Gomma abbruggiata, Coralli abbruggiati, Gomma Tragacanta, Acazia, Ipociftide, Balauftio, Maftice Lacca, Semi di Papavero negro arruftito ana aurei 2 . Incenfo, Zaffara. no, Opio ani aureo uno, e mezzo.

Si fanno Trocifci d'una dramma l'uno, con la mecagine di Semi di Pfillio .

Fucoltà, ed U/o.

Famoftagnare il fangue, da qualfivoglia parte del corpo che vien fuori.

Description of the original recipe, according to Donzelli (1737)

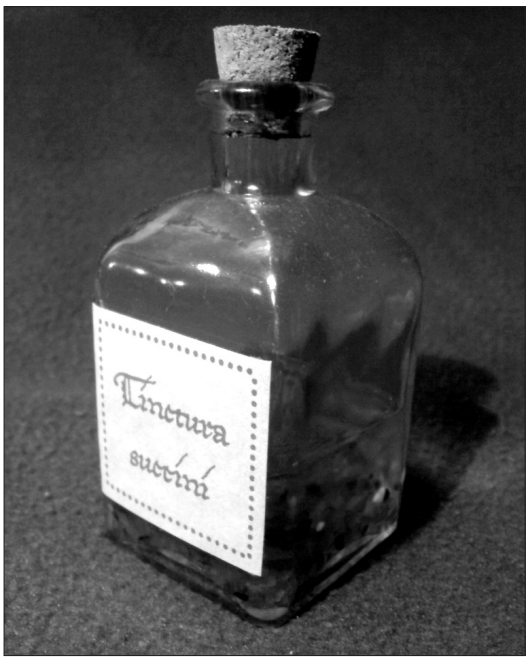

The tincture of amber 
Tintura di succino (amber tincture): it was prepared extracting amber with alcohol for 15 days ( 1 part of pulverised amber with 5 parts of alcohol) it was used as external application in the treatment of cutaneous ulcers and wounds. ${ }^{50}$

Magisterio di succino (magisterie of amber): it was obtained employing pulverised amber, mixed with distilled wine ("spirito di vino", spirit of wine), then boiled for a long time, and finally filtered and precipitated with "spirito di vitriolo" (vitriol spirit, that is sulphuric acid; so called because formerly obtained by the distillation of green vitriol, ferrous sulphate) or with citron or lemmon juice. It was used against many diseases, but especially for pestis. ${ }^{51}$

\section{Evolution of Amber Use in Medicine}

After centuries of wide use of amber in medicine, at the end of XIX century, with the evolution of patho-physiological medicine following experimental evidence-based criteria, doubts arose about most of the above mentioned supposed medicinal properties of amber. Pliny had already reported [Naturalis Historia, liber XXXVII, chapter III]: "Ma io l'ho per cosa falsa [...] quello che si dice della sua medicina, che bevendola rompe la pietra nella vescica, e guarisce il mal caduco bevendola col vino, o portandola addosso" (I know for sure it is false what is said about [amber] medical properties, that it brakes kidney stone and heals epilepsy by drinking it with wine or wearing it). Domenico Bruschi, Professor of Materia Medica and Botany at the University of Perugia (Italy), in his treatise Istituzioni di Materia Medica (1834), raised several doubts about the effectiveness of amber and of succinic acid in therapy. He suggested that all the formulations of amber contained many other substances, which more likely were the cause of an observed clinical effect; the author wrote that never a study on the activity of the single amber component had been performed. Of the same opinion were Dr. Hermann Nothnagel of the University of Friburg (Manuale di Materia Medica e Terapia, Italian edition of 1876), ${ }^{52}$

50 Bosio C. O. Trattato di Farmacologia Veterinaria o Materia Medica. - Torino: UTET, 1889.

51 Donzelli G. Teatro Farmaceutico, Dogmatico, e Spagirico del Dottor Giuseppe Donzelli. - Venezia: Andrea Poletti, 1737.

52 Nothnagel E. Manuale di Materia Medica e Terapia. - Napoli: Giovanni Jovene Libraio Editore, 1876. 
and C. Ruata, professor of Materia Medica at the University of Padua. The latter wrote in his Farmacopea Nazionale e Generale: "Ai nostri giorni pare caduto intieramente e meritamente in disuso". 53 (Today [amber] seems completely and deservedly fallen into disuse). The era of amber in medicine could be considered concluded. Both the first edition of the Italian Pharmacopoeia (1892) and the French Pharmacopoeia (1908 edition), did not include amber as medicines of therapeutical relevance. Even several years before, the British pharmacologist Jonathan Pereira (1804-1853) in his work The Elements of Materia Medica (1839) had stated: "It is not employed as a medicine in this country", although he admitted that "It was formerly used in chronic catarrhs, amenorrhea, hysteria, \& c., and was given either in the form of powder, in doses of from ten grains to a drachm, or in that of tincture, a formula for which is contained both in the French Codex and Prussian Pharmacopoeia." 54

Most reports about amber use in ancient medicine regard therapy indications, while no toxicity or adverse effects were mentioned. Only more recently, side effects were reported with the use of amber derivatives in therapy. Cantani (1887) referred the observations of Hallwachs and Schottin, who assumed succinic acid in doses ranging 1-8 grams: they experienced headache and heat in all skin with copious sweating. Regarding side effects of amber, a curious observation was presented in a book (written in Latin), part of the Opera Omnia Anatomico-Medico-Chirurgica of Fredericus Ruysch ${ }^{55}$. The author, whose portrait is presented in the book, was a medical doctor, professor of Anatomy and Botanics in Amsterdam. In chapter IV of his Observationes Anatomicae, the Observatio XLIV with the title Succini Globulus diu in Naribus haerens topho obductus presents the case of a girl who at the age of five introduced for fun a globe of amber into a nostril and there it remained for several years, despite producing

53 Ruata C. Farmacopea Nazionale e Generale. Materia Medica e Terapia. - VeronaPadova: Drucker \& Tedeschi, 1883.

${ }^{54}$ Pereira J. The Elements of Materia Medica; the natural history, preparation, properties, composition, effects, and uses of medicines. - Plinio il Vecchio, Naturalis Historia / Italian translation by Ludovico Domenichi, Pietro Ricciardi. Venezia, 1603. - London: Longman, 1839.

55 Ruysch F. Opera Omnia Anatomico-Medico-Chirurgica. - Amsterdam: Waesbergios J., 1737. 
discomfort. No one recognised the cause of the trouble until she was fourteen years old, when she suddenly sneezed and gave out the amber globe, partially covered by a probable stone concretion. The piece of amber presented a central hole, and this may suggest that it was probably a grain of a necklace, or a pendant, so frequently used as "externally administered" medicine. Surely a more accurate examination of the causes of the pain at the nose suffered by the little girl would have suggested what had happened and would have indicated an easy way to remove the unwanted amber. Following conclusion can be drawn: despite almost ten years of permanence in contact with the nasal mucous membrane, amber had been well (or supposed to be well) tolerated. A modern article confirms this fact: amber is not allergenic ${ }^{56}$, since no cutaneous sign of hypersensitisation was produced by an extract of amber (so ladies can wear amber necklaces without fear of allergy).

According to the report that amber is well tolerated by the skin ${ }^{57}$, supporting the idea that amber can be considered a biocompatible material. In the 1930s doctors used amber containers for blood transfusion, in order to minimise the clotting. ${ }^{58,59,60,61}$ In this context, it is interesting to note that an investigation by $\mathrm{Gibb}^{62}$ demonstrated a curious affinity between human blood surface antigens and fossil resins.

${ }^{56}$ Karlberg A. T., Boman A., Liden C. Studies on the allergenicity of Baltic amber // Contact Dermatitis, 1992; 27: 224-229.

57 Ibid.

58 Anonymous. Ortus sanitatis: Tractatus de lapidibus. - Strasbourg: Johann Prüss, 1497; Anonymous. I1 $91^{\circ}$ Congresso dei Naturalisti e Medici Tedeschi // Giornale di Chimica Industriale ed Applicata, Anno XII, 1930; 10: 505.

59 Neubauer O., Lampert H. Ein neuer Bluttransfusionapparat. Zugleich ein Beitrag zur Kenntnis der thrombagogen Eigenschaften fester Stoffe // Münchener Medizinische Wochenschrift, 1930; 77: 582-586.

60 Maxon H. Der neue Bluttransfusionapparat "Athrombit" // Medizinische Welt, 1931; 5: 1684.

${ }^{61}$ Schulz S. Bluttransfusiongeräte aus "echtem" und "Kunst-Bernstein" / Bernstein, Tränen der Götter, Glückauf Edition. - Essen: Verlag Glückauf GmbH, 1997. Pp. 465-474.

${ }^{62}$ Gibb B. Blutgruppenähnliche Substanzen im Bernstein, in anderei Naturharzen und in Nadeln einheimischer Koniferen // Acta Biol. Med. Germ., 1975; 34: 937-940. 


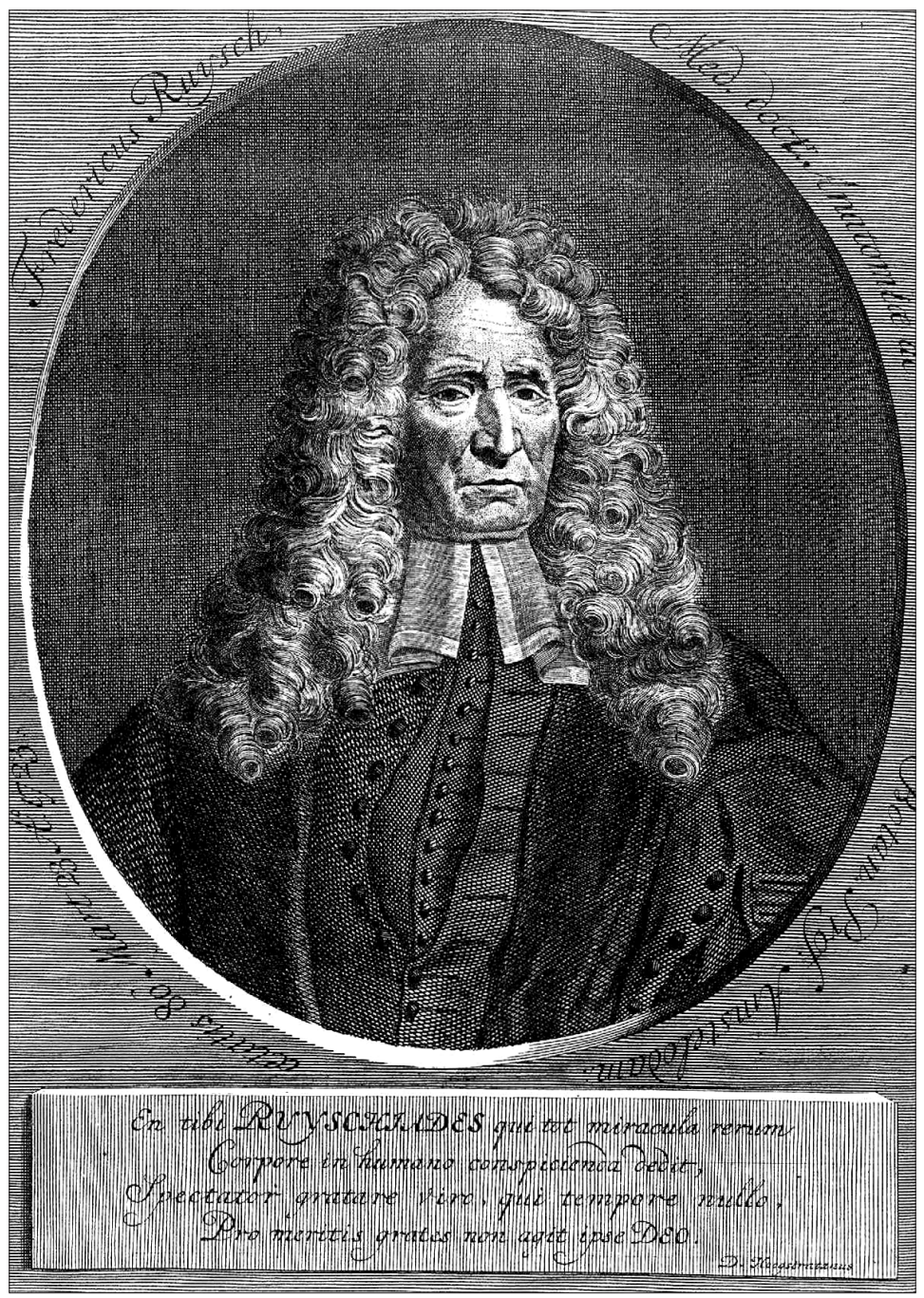

$$
000 . F^{\circ}
$$

The portrait of the Dutch anatomist and botanist Fredericus Ruysch (1638-1731). Lower image from his Opera Omnia (1734) showing the piece of amber retained in a young girl's nostril 
Recent studies by Kaiserling et al.63, 64, 65 have, however, definitely shown that inhalation of amber dust, such as in amber carving, can seriously damage lungs and cause a chronic disease, named "chronic amber lung". It remains to be clarified which is the role of amber dust or that of the silica dust contained in materials for polishing.

According to the modern tendency towards the so-called "natural" remedies, amber has been finding a revival in unconventional medicine, in particular in countries where there is much availability of this material, such as countries of North Europe. So we can find also today the use of succinic acid ${ }^{66}$, or of powdered amber, in particular in homeopatic products $67,68,69$, and in cosmetic ointments or body detergents. Also in traditional Chinese medicine ${ }^{70}$, amber ( $h u$ po), especially as powder (hu po san) has been used for a long time. In modern times, some reports suggested some efficacy of amber in the treatment of various diseases, such as coronary angina pectoris. ${ }^{71}$ The authors reported a significant improvement of general symptoms, physical strength, lipid metabolism parameters, electrocardiographic pattern and microcirculation. It is to note, however, that

${ }^{63}$ Kaiserling E., Kaiserling K., Müller K.-M., Weissert R. \& Berthold Chr. Cell and tissue reactions to amber in man and the rat. Skin morphology and immunological findings // Prace Muzeum Ziemi, 2004; 47: 129-140.

${ }^{64}$ Kaiserling E., Kaiserling K., Müller K.-M. Zelluläre Reaktionen auf Bernstein Zum tierexperimentellen Nachweis einer "Bernsteinlunge" // Pathologe, 2006; 27 (3): 188-192.

${ }^{65}$ Kaiserling E., Kaiserling K., Mueller K.-M., Weissert R., Berthold C. Cell and tissue reactions to amber in human cell cultures and the rat lung // Prace Muzeum Ziemi, 2008; 49: 97-107.

66 Gierłowski W. Sukcynit - żywy kamień // Polski Jubiler, 2002; 1 (15): 22-24.

${ }^{67}$ Kosmowska-Ceranowicz B. Biomineralizacja i biomateriały. - Warszawa: PWN, 1991. - Pp. 152-163.

68 Kulicka R. The role of amber in religious beliefs and popular medicine // Amber, treasure of the ancients seas / Edited by B. Kosmowska-Ceranowicz. - Warszawa: Oficyna Wydawnicza Sadyba, 1998. - Pp. 20-21.

69 Gierłowski W. Sukcynit - żywy kamień // Polski Jubiler, 2002; 1 (15): 22-24.

70 Wu J.-N. An illustrated Chinese Materia Medica. - New York: Oxford University Press, 2005.

71 Yuan J., Guo W., Yang B., Liu P., Wang Q., Yuan H. 116 cases of coronary angina pectoris treated with powder composed of radix ginseng, radix notoginseng and succinum // J. Tradit. Chin. Med., 1997; 17 (1): 14-17. 
the formulation they used contains, besides amber (succinum), also Radix Ginseng and Radix Notoginseng, which are herbal remedies whose composition in ginsenosides may be responsible for the observed clinical effects. A recent publication confirms that an extract of Panax notoginseng given as intracoronary injection, is effective in increasing the coronary blood flow. ${ }^{72}$ Similarly, several other Chinese formulations which contain amber are mixtures of several other substances, and, therefore, it is impossible to detectan effect due to amber, if any. Homeopatic formulations including amber are suggested for the treatment of asthma and other bronchial/ pulmonary pathologies. ${ }^{73}$ Some products are sold as tonics, against stress, against ageing problems, as immunostimulants and against the damages produced by alcohol, as claimed by Rebound ${ }^{\circledR}$ Hangover formula (containing $250 \mathrm{mg}$ of succinic acid per tablet).

Also today in the Baltic region, women that suffer of goitre wear a necklace of raw amber, referred effective according to the people that have used it, as consequence of its electrostatic properties, but a scientific evaluation is still in need of further research.

A study conducted by Chen et $\mathrm{al}^{74}$ on a behavioural animal model in rat demonstrated that oral administration of pure succinic acid (3 and $6 \mathrm{mg} / \mathrm{kg}$ body weight) may have anxiolytic activity, although higher doses failed to produce that effect.

Another investigation in the rat showed the gastroprotective effect of a herbal preparation produced in India $\left(\right.$ Ambrex $^{\circledR}$ ), containing $15 \%$ of amber $^{75}$. This formulation is commercially available for human use in capsules containing $37.5 \mathrm{mg}$ of amber each. The association of amber with

${ }^{72}$ Gan L. J, Zhang C. H, Zhang M. Effect of intracoronary injection with xuesaitong in treating post-PCI slow-reflow phenomenon in patients with ST-segment elevation myocardial infarction // Zhongguo Zhong Xi Yi Jie He Za Zhi, 2010; 30 (4): 348-351.

${ }^{73}$ Kaiserling K. Baltischer Bernstein. Seine Verwendung in der Medizin, historischer Rückblick und aktuelle Perspektiven // Pathologe, 2001; 22 (4): 285-286.

${ }^{74}$ Chen S. W., Kong W. X., Min L., Li J. F. Anxiolytic-like effect of succinic acid in mice // Life Sciences, 2003; 73: 3257-3264.

75 Narayan S., Devi R. S., Jainu M., Sabitha K. E., Shyamala Devi C. S. Protective effect of apolyherbal drug, ambrex in ethanol-induced gastric ulcers // Indian J. Pharmacol, 2004; 36: 34-37. 
several plant extracts makes it again difficult to define any true therapeutic role of amber. We can just conclude remembering that amber has aroused curiosity in mankind since ancient times, and it still continues in many ways, also today.

\title{
Acknowledgements
}

The author wishes to thank Dr. Juris Salaks (Pauls Stradiņš Museum of History of Medicine, Rìga) for the encouragement to submit the present article; Roberta Sato and Francesca Chinaglia (Librarians of the Department of Pharmacology, University of Padova, Italy), and Katarzyna Czaykowska (Poland) for the help in the search of ancient texts.

Appendix

\begin{abstract}
Old treatises and theses discussing uses of amber in medicine m $^{76}$
\end{abstract}

\begin{tabular}{|c|c|}
\hline $\begin{array}{c}\text { Year(s) of } \\
\text { publication }\end{array}$ & Author $\cdot$ Title $\cdot$ Place of publication \\
\hline 1 & 2 \\
\hline $\begin{array}{l}1551(1562 \\
1573,1619)\end{array}$ & Aurifaber A. Succini historia. Regiomonti (Königsberg) \\
\hline 1555 & $\begin{array}{l}\text { Peucer K. Propositiones de origine et causis Succini. } \\
\text { Wittebergae (Wittenberg) }\end{array}$ \\
\hline $1558(1565)$ & Goebelius S. De Succino libri duo. Francofurti (Frankfurt) \\
\hline 1583 & $\begin{array}{l}\text { Hermann D. De rana et lacerta, succino Prussiaco insitis } \\
\text { Danielis Hermanni Prussi discursus philosoficus. Cracoviae } \\
\text { (Kraków) }\end{array}$ \\
\hline
\end{tabular}

(cont. on p. 232)

76 Reference list is from: Waring E. J. Bibliotheca therapeutica, or, Bibliography of therapeutics, chiefly in reference to articles of the materia medica, with numerous critical, historical and therapeutical annotations, and an appendix containing the bibliography of British mineral waters. - Vol. II. - London: The New Sydenham Society, 1879. - Pp. 700-701;

Pritzel G. A. Thesaurus literaturae botanicae omnium gentium inde a rerum botanicarum initiis ad nostra usque tempora, quindecim millia operum recenses. - Leipzig, 1851. - P. 422. 


\begin{tabular}{|c|l|}
\hline 1 & \multicolumn{1}{|c|}{ 2 } \\
\hline 1587 & $\begin{array}{l}\text { Baumgarten J. Der köstliche Agtstein oder Börnstein. } \\
\text { Magdeburgi (Magdeburg) }\end{array}$ \\
\hline 1590 & Wigand J. Vera historia de Succino Borussico. Jenae (Jena) \\
\hline 1604 & Zoelner B. De Succino. Lipsiae (Leipzig) \\
\hline 1612 & $\begin{array}{l}\text { Schulze G. P. De Succino Marchico, aliisque naturae donis. } \\
\text { Thorunii (Torun) }\end{array}$ \\
\hline 1614 & Pauli A. De Succini natura. Dantisci (Gdansk) \\
\hline 1636 & Crüger J. B. De Succino. Regiomonti (Königsberg) \\
\hline $1648(1668)$ & $\begin{array}{l}\text { Thilo G. (Resp. Graeber K.). De Succino. Wittebergae } \\
\text { (Wittenberg) }\end{array}$ \\
\hline 1660 & Concius A. De Succino. Regiomonti (Königsberg) \\
\hline 1660 & $\begin{array}{l}\text { Gruenberg F. Exercitatio physica de Succino. Regiomonti } \\
\text { (Königsberg) }\end{array}$ \\
\hline 1663 & $\begin{array}{l}\text { Thilo I. Diss. de Succino Borussorum, prima, nomina, } \\
\text { descriptionem et materiam ejus exhibens. Lipsiae (Leipzig) }\end{array}$ \\
\hline 1671 & Schelwig S. Theses de Succino. Thorunii (Torun) \\
\hline 1671 & $\begin{array}{l}\text { Schenckius J. T. (Resp. Schultz G.). De Succino. Jenae } \\
\text { (Jena) }\end{array}$ \\
\hline 1677 & $\begin{array}{l}\text { Hartmann P. J. Succini Prussici physica et civilis historia. } \\
\text { Francofurti (Frankfurt) }\end{array}$ \\
\hline 1682 & Kemper T. (Resp. G. W. Blemberg) De Succino. Jenae (Jena) \\
\hline 1699 & $\begin{array}{l}\text { Hartmann P. J. Succincta Succini Prussici historia et } \\
\text { demonstratio. Berolini (Berlin) }\end{array}$ \\
\hline $1725-1728$ & $\begin{array}{l}\text { Vesti J., Silberschlag J. E. Succinum, physicê et medicê } \\
\text { consideratum. Erfordiae (Erfurt) }\end{array}$ \\
\hline 1728 & $\begin{array}{l}\text { Hartmann M. P. De Succino ejusque summa in medicina } \\
\text { efficacia. Lugduni Batavorum (Leiden) }\end{array}$ \\
\hline Sendel N. Electrologiae Missus I-III, Elbingae (Elbląg) \\
\hline Kulm J. A. De Succino. Gedani (Gdansk) \\
\hline Regiomonti (Königsberg)
\end{tabular}




\begin{tabular}{|c|l|}
\hline 1 & \multicolumn{1}{|c|}{ 2 } \\
\hline 1737 & Ancher P. De Succino. Hauniae (Copenhagen) \\
\hline 1737 & $\begin{array}{l}\text { Rappolt K. H. De origine Succini in litore Sambiensi } \\
\text { meditatio. Regiomonti (Königsberg) }\end{array}$ \\
\hline 1742 & $\begin{array}{l}\text { Sendel N. Historia Succinorum corpora aliena involventium. } \\
\text { Lipsiae (Leipzig) }\end{array}$ \\
\hline 1750 & Alberti M. (Resp. Baumer J.). De Succino. Halae (Halle) \\
\hline 1760 & $\begin{array}{l}\text { Stokar de Neuforn J. G. De Succino in genere et speciatim in } \\
\text { Succino fossili Wilholzensi. Lugduni Batavorum (Leiden) }\end{array}$ \\
\hline 1767 & $\begin{array}{l}\text { Bock F. S. Naturgeschichte des preussischen Bernsteins. } \\
\text { Königsberg }\end{array}$ \\
\hline 1770 & Cooke J. Natural History of Lac, Amber, and Myrrh. London \\
\hline 1783 & $\begin{array}{l}\text { Ploucquet G. G. De Vernicis Succinatae vi eximia in } \\
\text { Sanandis Ambustionibus.Tubingae (Tübingen) }\end{array}$ \\
\hline 1794 & $\begin{array}{l}\text { Hecker J. L. (Praes. Hoffmann F. X.). Diss. de Succino, ejus } \\
\text { characteribus, origine et usu. Heidelbergae (Heidelberg) }\end{array}$ \\
\hline 1796 & $\begin{array}{l}\text { Hasse J. G. Der aufgefundene Eridanus: oder neue } \\
\text { Aufschlüsse über den Ursprung, die Zeit der Entstehung, } \\
\text { das Vaterland und die Geschichte des Bernsteins. Riga }\end{array}$ \\
\hline 1816 & John J. F. Naturgeschichte des Succins. Cöln (Köln) \\
\hline 1819 & Schweiqger A. F. Bemerkungen über den Bernstein. Berlin \\
\hline 1821 & $\begin{array}{l}\text { Graffenauer J. P. Histoire naturelle, chimique et technique, } \\
\text { du Succin ou Ambre jaune. Strasbourg et Paris }\end{array}$ \\
\hline 1845 & $\begin{array}{l}\text { Aycke J. C. Fragmente zur Naturgeschichte des Bernsteins. } \\
\text { Danzig (Gdansk) }\end{array}$ \\
\hline $\begin{array}{l}\text { von Roy C. W. Ansichten über Entstehung und Vorkommen } \\
\text { des Bernsteins. Danzig und Leipzig }\end{array}$ \\
\hline $\begin{array}{l}\text { Steinbeck A. Ueber die Bernsteingewinnung und das } \\
\text { Braunkohlenlager bei Brandenburg a.d. Havel. Brandenburg }\end{array}$ \\
\hline $\begin{array}{l}\text { Goeppert et Berendt. Der Bernstein und die in ihm } \\
\text { befindlichen Pflanzenreste der Vorwelt. Berlin }\end{array}$ \\
\hline 1840
\end{tabular}




\section{Dzintars - saules akmens - antīkajā medicīnā}

\section{Kopsavilkums}

Dzintars, dārgakmens, saules akmens bija ļoti iecienīts antīkajā pasaule jau kopš senatnes. Tas tika plaši izmantots arī kā amulets un ārstniecības līdzeklis. Vairumā izcilāko pagātnes medicīnas traktātu tika aprakstītas dzintara dziednieciskās īpašības un sniegtas ziņas par tā izmantošanu medikamentu receptūrā (kompozīijāa) līdz pat XIX gadsimta vidum. Modernajā medicīnā dzintara dziednieciskās īpašības tika apšaubītas, un dzintars pakāpeniski izzuda no vairuma farmakopeju. Tā izmantošana praktiskajā medicīnā gandrīz izsīka.

Eugenio Ragazzi, Dr. med., Professor

University of Padua

eugenio.ragazzi@unipd.it 